\title{
Corporate Financial Performance Analysis Due to The Issuance of Global Bond Using Economic Value Added (EVA) Method: Case Study of PT XYZ
}

\author{
Yusufa R Dibyoseputro ${ }^{1}$, Junino Jahja ${ }^{2}$ \\ \{yusufa.r91@ui.ac.id'1,junino.jahja@ui.ac.id² \\ Universitas Indonesia, Indonesia ${ }^{12}$
}

\begin{abstract}
The purpose of this research is to describe PT XYZ, company engaging in Textile and Product Textile Industry ("TPT Industry") the effect of Global Bond issuance pursuant to the corporate financial performance and value-added creation. TPT Industry face many challenges and obstacles that may lead to company financial distress which already happen in emerging country such as Indonesia. The calculation towards company financial performance are using Economic Value Added ("EVA") method. This research conducted on $2014-2019$ period. PT XYZ will be compared with four others TPT Industry company which are the top highest market capitalization company in Indonesia. The result of EVA calculation shows that the EVA score of target company and comparison company are mostly negative. Company in TPT Industry must understand financial policy alternative to avoid financial distress condition. The appropriate and exact financial policy grant the company ability to overcome global economic volatility, international trade, competition, and trade war.
\end{abstract}

Keywords: Corporate Finance, Economic Value Added, Financial Performance, Textile and Garment Industry, Public Company, and Global Bonds.

\section{Introduction}

TPT Industry is one of the prioritized and developed industries in Indonesia due to its contribution to the net foreign exchange of export and the utility of manpower [1]. Based on the Asosiasi Pertekstilan Indonesia (API), between 2012 and 2016, the export of textile and product textile is saturated. However, with all of the incentives and potential markets that the TPT Industry had, this industry also faces many challenges and threats, both domestic or international [2]. In 2018, the global economic condition faced an imbalance such as slow economic growth and financial market uncertainty [3]. This condition resulted in the deterioration of trade relations between countries which resulted in a decrease in global trade volume. Based on the World Bank, global economic growth is declined due to the low growth of European countries and the slow economic growth in China [4]. To answer these challenges and threats, the textile company must endure and overcome this problem by make an appropriate financial policy or corporate action. This leads us to the main problem for a company during this condition which are: (i) The ability of value added creation; and (ii) Appropriate financial policy.

PT Sri Rejeki Isman (“SRIL") was established in 1966 by H. M. Lukminto. SRIL engages in the TPT Industry. SRIL conduct its business in Sukoharjo, Central Java which obtains four production lane, which are: (i) Spinning; (ii) Weaving; (iii) Dying, Printing and Finishing; and (iv) Garment. In 2013, SRIL conducted an Initial Public Offering in Indonesia Stock 
Exchange to increase the financial performance and company operational that are decreasing. Until the 2020, SRIL already issued Global Bond twice which are: (i) In 2016, SRIL issued a Global Bond with the value of USD 350.000.000 which will be matured on 2021, interest rate of $8.25 \%$, Moody's B1 rating, and lead manager by Citigroup (“Global Bond I”); and (ii) In 2017, SRIL issued a Global Bond with the value of USD 150.000.000 which will be matured on 2024, interest rate of $6.875 \%$, Moody's B1 rating, and lead manager by DBS Bank Ltd. ("Global Bond II"). Information regarding the Global Bond issued by SRIL are based on Global Bond prospectus and public information.

\section{Literature Review}

\subsection{Bonds}

Bonds or debt securities are categorized as a securities listed in the stock exchange together with stocks, sukuk, asset-backed securities, or real estate investment funds [5]. Bond can be defined as a medium-term or long-term debt instruments which can be transferable to other party and contain an obligation by the issuers to pay an interest amount in certain periods and pay off the principal amount at the maturity date specified to the purchaser of the bonds ("Bonds") [6]. Bonds shall be issued by private companies either public or private companies and the government itself ("Bond Issuers") [7]. Individuals or legal entities that have interest on buying a Bonds but not legally and bindingly purchased the Bonds are still considered as potential investors ("Investors").

\subsection{Global Bonds}

The international bond market is a capital market containing a debt securities instrument. The international bond market consists of Bond Issuers and Investors which are currently increase in emerging countries [8]. An alternative that is often chosen in the international bond market is the Global Bonds and Eurobonds [5]. Global bonds are generally issued under US Rule 144A and Eurobonds regulations. Global bonds are bonds issued and sold publicly by Bond Issuers on the bond market outside the domicile of the Bond Issuers ("Global Bonds") [8].

\subsection{Economic Value Added}

Economic Value Added is a value-based financial performance measurement [9]. EVA is a re-combination of existing financial management and corporate financial principles that can be implement in any kind of industries [10]. EVA is a calculation from the differences between return and invested capital from the cost of capital of a company, that enable to measure the financial performance of a company [11]. EVA is a calculation of residual income from the subtraction of Cost of Capital from Operating Profit in a business operation [12]. EVA may measure the real company profitability because utilize as an instrument of value creation for the shareholders [13].

EVA was invented and developed firstly by Joel Stern and G Bennet Stewart III on 1982 and registered as a copyright by Stern \& Stewart Company [14]. EVA is an appropriate measurement model to show the company ability to survive among its competitors in the industry [9]. EVA are one of the modern corporate financial instrument that may measure the performance of the company in a simple way yet can explained a complex management 
system [15]. EVA may be used as a portfolio measurement model due to its accuracy in explaining corporate performance [16]. To implement EVA in a company, there must be an accounting adjustment that must be conducted [17]. To find Weighted Average Cost of Capital, there are also calculation of Cost of Equity and Cost of Debt [18]. Furthermore, EVA calculation are as follows [11], [18]:

\section{EVA $=$ Net Operating Profit After Tax - (Invested Capital $x$ Weighted Average Cost of Capital).}

After doing the abovementioned calculations, the results of the EVA calculation can be analysed in the following manner [19]: (i) EVA $>0$, explained that company succeed in create added value and achieve its target; (ii) $\mathrm{EVA}=0$, explained that company failed to create added value and failed to achieve its target; and (iii) EVA $>0$, explained that company unable to create added value and failed to achieve its target [13].

\section{Method}

\subsection{Research Scheme}

This research was conducted using case study approach to find out the full picture of a company financial performance that shall be fully investigated. To improve the analytical quality compared to previous research. This research also analyze the Global Bond issuance pursuant to the financial performance, this research also explain about: (i) Risk factors; (ii) Cashflow feasibility; and (iii) Government bond rating. Those factors mainly explain about the feasibility analysis of this financial policy from the company and Investors. The research methodology scheme are as follows [20], [21]:

a) Literature study conducted to obtained information regarding: (i) Debt securities; (ii) Global bonds or international bonds; and (iii) Literature review of Economic Value Added (EVA).

b) Data Collection conducted from SRIL and Comparison Company annual report and management report. Interview with correspondent from PT XYZ management regarding the research topic.

c) Data processing conducted from the SRIL using the EVA method before the issuance of Global Bonds and upcoming financial years after the issuance of Global Bond 2014 2019 ("Research Period").

d) Result Comparison conducted by Comparing EVA value from comparison company and SRIL using EVA method upon the issuance of Global Bonds.

e) Discussion and analysis obtained from Corporate financial performance analysis between the SRIL and Comparison Company using EVA method. Timeframe of the comparison analysis is prior and upon the issuance of Global Bonds of SRIL.

\subsection{Comparison Company}

The listed company that chosen as a comparison company must have the following criteria: (i) Market Cap above IDR 50 Billion; (ii) Listed in the IDX Main Board; (iii) Engage in TPT Industry; and (iv) Listed in IDX in period of 1990 - 2013. The comparison company 
are: (i) PT Pan Brothers Tbk ("PBRX”); (ii) PT Indo Rama Synthetic Tbk ("INDR"); (iii) PT Buana Artha Anugerah Tbk (“STAR"); and (iv) PT Ever Shine Tex Tbk (“ESTI”).

\section{Results And Discussion}

The result stated below are the EVA Score of SRIL and Comparison Company:

Table 1. EVA Score of SRIL

\begin{tabular}{|c|c|c|c|c|c|c|}
\hline SRIL & $\mathbf{2 0 1 4}$ & $\mathbf{2 0 1 5}$ & $\mathbf{2 0 1 6}$ & $\mathbf{2 0 1 7}$ & $\mathbf{2 0 1 8}$ & $\mathbf{2 0 1 9}$ \\
\hline $\begin{array}{c}\text { NOPA } \\
\text { T }\end{array}$ & $49,469,394$ & $48,438,525$ & $49,520,843$ & $54,105,856$ & $74,560,006$ & $76,161,670$ \\
\hline $\begin{array}{c}\text { INV- } \\
\text { CAP }\end{array}$ & $766,293,79$ & $719,991,77$ & $926,013,02$ & $1,289,098,63$ & $1,300,576,09$ & $1,598,153,21$ \\
\hline CoD & $4.81 \%$ & $5.89 \%$ & $6.64 \%$ & $5.79 \%$ & $5.39 \%$ & $5.57 \%$ \\
\hline CoE & $10.51 \%$ & $10.87 \%$ & $9.93 \%$ & $9.97 \%$ & $9.84 \%$ & $10.07 \%$ \\
\hline WACC & $6.71 \%$ & $7.65 \%$ & $7.79 \%$ & $7.34 \%$ & $7.08 \%$ & $7.28 \%$ \\
\hline EVA & $-1,952,856$ & $-6,629,151$ & - & $-40,529,203$ & $-17,457,535$ & $-40,198,926$ \\
\hline
\end{tabular}

Source: Author Calculation

Table 2. EVA Score of SRIL and Comparison Company

\begin{tabular}{|l|l|l|l|l|l|l|}
\hline EVA & $\mathbf{2 0 1 4}$ & $\mathbf{2 0 1 5}$ & $\mathbf{2 0 1 6}$ & $\mathbf{2 0 1 7}$ & $\mathbf{2 0 1 8}$ & $\mathbf{2 0 1 9}$ \\
\hline SRIL & $\mathbf{- 1 , 9 5 2 , 8 5 6}$ & $\mathbf{- 6 , 6 2 9 , 1 5 1}$ & $\mathbf{- 2 2 , 6 3 4 , 0 9 0}$ & $\mathbf{- 4 0 , 5 2 9 , 2 0 3}$ & $\mathbf{- 1 7 , 4 5 7 , 5 3 5}$ & $\mathbf{- 4 0 , 1 9 8 , 9 2 6}$ \\
\hline PBRX & $-23,227,235$ & $-18,454,428$ & $-18,120,734$ & $-25,773,124$ & $-24,950,620$ & $-26,774,039$ \\
\hline STAR & $-5,159,288$ & $-4,508,273$ & $-4,152,988$ & $-3,973,421$ & $-3,050,695$ & $3,861,066$ \\
\hline INDR & $-29,656,348$ & $-43,603,253$ & $-28,739,252$ & $-23,622,015$ & $\mathbf{1 6 , 7 3 8 , 9 9 1}$ & $-5,184,622$ \\
\hline ESTI & $-8,802,392$ & $-7,164,339$ & $\mathbf{1 3 8 , 1 4 9}$ & $-3,674,150$ & $-1,353,061$ & $-734,600$ \\
\hline
\end{tabular}

Source: Author Calculation

The EVA value of SRIL during the Research Period was negative and in decreasing pattern. This explains that SRIL failed to create added value, unable to meet company targets, and have a possibility unable to settle investor or creditor obligations. However, this condition does not explain that SRIL unable to fulfil its obligation to its Investor, Creditors, and Stakeholders. There are many indicators that can be used to identify the feasibility of Global Bond issuance. The EVA value of the Comparative Company in the Research Period mostly are negative, except ESTI in 2016 and INDR in 2018 that obtained positive EVA value. This positive value means that the company has succeeded in creating added value, achieving the company's target, and being able to fulfill the liability of the Investor or Creditors. The growth patterns of EVA values from SRIL and Comparative Companies are:

1. EVA value with an increasing pattern: STAR, INDR, and ESTI, which means financial performance are increasing 
2. EVA value in the decreasing pattern: SRIL and PBRX which means financial performance are decreasing.

Negative EVA value in the Comparative Company is an indicator of TPT industry is experiencing market sophistication which causes pressure on the industry [22]. This condition may impact on companies to an event of default and leads to financial distress. EVA value which shows an increase pattern or positive value are due to conduct several corporate actions such as: (i) Restructuring the company's debt; (ii) Transfer of company assets; (iii) Changing the company's short-term strategy; or (iv) Liquidation of company assets [14]. ESTI in 2016 and INDR in 2018 succeed to obtain positive EVA value due to disposal of assets which is in accordance to the theoretical framework to improve EVA value.

Global Bond I and Global Bond II are issued by SRIL with the aim to obtained alternative funding from the international bond market. Global Bond issued by SRIL categorized as a High Yield Bond due to the results of non-investment grade ratings from Moody's and Fitch. Global Bond Issuers are considered to have low ability to fulfil obligations to investors and creditors. However, this condition does not make Global Bond from SRIL entirely a bad investment. High Yield Bond is an appropriate investment instrument to diversify assets. Besides that, the value of the interest coverage ratio from SRIL still shows a good and reasonable score which is on average of 1.56. This shows that SRIL is able to fulfil interest payment obligations during the trading period.

Investment in Global Bond from SRIL has a risk factors that must be considered by Investors. Referring to Moody's and Fitch's assessment on the Indonesia government bond rating are categorized as investment grade or $\mathrm{Baa} 3$ and rising towards $\mathrm{Baa} 2$ during the Research Period. This condition explains that economic conditions in Indonesia are stable and have positive developments. This gives support and positive confidence to investors in investing in Indonesia. This include investing in SRIL Global Bond. Investors must understand the risk factors of SRIL Global Bonds such as: (i) Market and TPT Industry Conditions; (ii) Currency risk; (iii) Domestic and international business competition; (iv) Debt obligations from SRIL; and (vi) SRIL's ability to control Cashflow.

SRIL's financial performance pursuant to the EVA value after the issuance of Global Bond is experiencing a declining pattern during the Research Period. Financial performance was successfully increase after the issuance of Global Bond II, but in 2017 simultaneously SRIL took several corporate actions such as: (i) Issuance of Notes Payable; (ii) Issuance of MediumTerm Notes; and (iii) Increase capital with right issues. In 2017 from a financial point of view, SRIL aim to restructure its corporate debt. This action resulted in an increase in EVA in 2018. However, in 2019, the value of EVA declined again drastically due to increased Cost of Debt due to SRIL's funding sources which are highly dependent on debt and continue to grow. SRIL in this case have a increasing pattern of Cost of Debt with an average score of $5.68 \%$. Issuance of Global Bond requires SRIL to pay interest payments which for High Yield Bonds is high. This payment of interest payment is one of the factors that burden SRIL's finances. However, the SRIL's interest coverage ratio is still at a reasonable score and able to fulfil the obligation.

\section{Conclusion}

The TPT industry is one of the manufacturing sectors that the development are prioritized especially in this industrial era 4.0. However, according to EVA results which are generally 
negative shows that TPT Industry are experiencing pressure due to: (i) Uncertainty in the global economy; (ii) slowing growth; and (iii) intense business competition both domestically and internationally. EVA calculation results from SRIL showed a negative value during the Research Period. SRIL did not succeed in creating added value and achieving the company's target. EVA value from SRIL also experienced a decreasing pattern where SRIL's financial performance was declining.

Company in TPT Industry which intend to issue a Global Bond must understand its company's financial characteristics and company specific information. By understanding these two variables the analysis and feasibility process of issuing a Global Bond can be clearly seen. Global Bonds issuer are expected to not have a high Cost of Debt or dependence on leverage financing. This is because the issuance of Global Bonds with high interest rates can burden the company's finance with debt. The company must also maintain an appropriate interest coverage ratio, to provide confidence to investors and creditors that the company is able to pay interest or liabilities. Global bond issuance may suitable for the company who want to conduct a debt restructuring or and additional working capital due to its easy and fast process. However, for a long-term financial performance, Global Bond may increase its debt level and may adversely affect the company financial performance. To increase long term financial performance, Global Bond cannot be utilized as a standalone instrument and must be supported by any other corporate actions as shown by SRIL on 2017.

\section{References}

[1] Neraca, "Kemenperin: Industri Tekstil dan Pakaian Tumbuh Paling Tinggi," Kemenperin, 2019. [Online]. Available: https://kemenperin.go.id/artikel/21230/Kemenperin:-Industri-Tekstil-danPakaian-Tumbuh-Paling-Tinggi. [Accessed: 13-Mar-2020].

[2] Sella Panduarsa Gareta, "Menperin sebut industri tekstil jadi sektor strategis," Antaranews.com, 2020. [Online]. Available: https://www.antaranews.com/berita/1251780/menperin-sebutindustri-tekstil-jadi-sektor-strategis.

[3] Antara, "Digempur Produk China, 188 Perusahaan Tekstil Bangkrut dalam 2 Tahun Terakhir," inews.id, 2019. [Online]. Available: https://www.inews.id/finance/bisnis/digempur-produkchina-188-perusahaan-tekstil-bangkrut-dalam-2-tahun-terakhir.

[4] R. Tri, "Perang Dagang, Industri Tekstil Untung Sekaligus Buntung," tempo.co, 2019. [Online]. Available: https://bisnis.tempo.co/read/1207701/perang-dagang-industri-tekstil-untungsekaligus-buntung.

[5] Zvi Bodie; Alex Kane; Alan J Marcus, Investments, Asia Globa. New York: McGraw-Hill, 2011.

[6] J. Hartono, Teori Portofolio dan Analisis Investasi, 11th ed. Yogyakarta: BPFE-Yogyakarta, 2017.

[7] Bursa Efek Indonesia, “Surat Utang (Obligasi),” Idx.co.id, 2019. [Online]. Available: https://www.idx.co.id/produk/surat-utang-obligasi/.

[8] A. Fuertes and J. M. Serena, "How firms borrow in international bond markets: Securities regulation and market segmentation," J. Financ. Regul. Compliance, vol. 26, no. 1, pp. 135169, 2018, doi: 10.1108/JFRC-11-2016-0100.

[9] F. Koç, "Economic Value Added Approach in Measurement of Financial Performance: An Investigation on Economic Added Values of Holdings and Investment Companies Processed in BIST 100 in Turkey.," J. Accounting, Financ. Audit. Stud., vol. 3, no. 4, pp. 109-136, 2017.

[10] A. Sabol and F. Sverer, "a Review of the Economic Value Added Literature and Application," UTMS J. Econ., vol. 8, no. 1, pp. 19-27, 2017.

[11] S David Young; Stephen F O'Byrne, EVA and value-based management: a pratical guide to 
implementation. New York: McGraw-Hill, 2001.

[12] G. B. Stewart, The Quest For Value: A Guide For Senior Managers. New York: Harper Business, 1991.

[13] James L Grant, Foundations of Economic Value Added, 2nd ed. Hoboken, New Jersey: John Wiley \& Sons, 2003.

[14] J. M. Stern and J. T. Willett, "A Look Back at the Beginnings of EVA and Value-Based Management,” J. Appl. Corp. Financ., vol. 26, no. 1, pp. 39-46, 2014, doi: 10.1111/jacf.12052.

[15] E. Malichova, M. Durisova, and E. Tokarcikova, "Models of application economic value added in automotive company," Transp. Probl., vol. 12, no. 3, pp. 93-102, 2017, doi: 10.20858/tp.2017.12.3.9.

[16] B. Stewart, "EVA, not EBITDA: A New Financial Paradigm for Private Equity Firms," J. Appl. Corp. Financ., vol. 31, no. 3, pp. 103-115, 2019, doi: 10.1111/jacf.12365.

[17] D. Balachandar, "Financial Evaluation of Firms Using Economic Value Added as a Performance Measure - A Comparative Study,” no. June, pp. 11-17, 2016.

[18] Stephen A Ross; Randolph W Westerfield; Jeffrey Jaffe; Bradford D Jordan, Corporate FInance, 9th ed. New York: McGraw-Hill, 2013.

[19] Y. Yusbardini, "Economic Value Added vs Firm Performance," Int. J. Econ. Perspect., vol. 11, no. 1, pp. 1683-1691, 2017.

[20] S. Jakub, B. Viera, and K. Eva, "Economic Value Added as a Measurement Tool of Financial Performance," Procedia Econ. Financ., vol. 26, no. 15, pp. 484-489, 2015, doi: 10.1016/s22125671(15)00877-1.

[21] Z. Xin'e, W. Ting, and Z. Yuan, "Economic Value Added for Performance Evaluation: A Financial Engineering," Syst. Eng. Procedia, vol. 5, pp. 379-387, 2012, doi: 10.1016/j.sepro.2012.04.059.

[22] G. Milano, "Beyond EVA," J. Appl. Corp. Financ., vol. 31, no. 3, 2019. 